\title{
FADS1 wt Allele
}

National Cancer Institute

\section{Source}

National Cancer Institute. FADS1 wt Allele. NCI Thesaurus. Code C82860.

Human FADS1 wild-type allele is located within 11q12.2-q13.1 and is approximately $17 \mathrm{~kb}$

in length. This allele, which encodes fatty acid desaturase 1 protein, is involved in the mediation of lipid metabolism. 